\title{
Comparison of advanced techniques for mechanical surface treatment of stainless steel parts
}

\author{
Lesyk $^{1 *}$ D.A., Soyama ${ }^{2}$ S., Mordyuk ${ }^{3}$ B.N., Martinez ${ }^{4}$ S., Dzhemelinskyi ${ }^{1}$ V.V., Lamikiz ${ }^{4}$ A., \\ ${ }^{1}$ Igor Sikorsky Kyiv Polytechnic Institute, Kyiv, Ukraine \\ 2 Tohoku University, Sendai, Japan \\ 3 Kurdyumov Institute for Metal Physics of the NAS of Ukraine, Kyiv, Ukraine \\ ${ }^{4}$ University of the Basque Country, Bilbao, Spain
}

\begin{abstract}
This work compares various mechanical surface treatment techniques applied to improve the properties of the AISI 304 austenitic stainless steel. Effects of laser shock peening (LSP), water jet cavitation peening (WjCP), water jet shot peening (WjSP), and ultrasonic impact treatment (UIT) on surface roughness, hardness, and residual stress were studied. The results demonstrate that as compared to the untreated specimen $(R a=3.06 \mu m)$, all strain hardening methods demonstrate the decreased surface roughness parameters. The smallest Ra parameter of the wavy regular surface microrelief is formed after the ultrasonic treatment. The surface hardness (22.1 HRC 5 ) was respectively increased by $30.7 \%, 38.4 \%, 69.6 \%$, and 73.2\% after the LSP, WjCP, WjSP, and UIT treatments. All peening techniques induced compressive residual stresses (ranged from-377 MPa to -693 MPa) in the near-surface layer. It is assumed that used treatments can increase wear/corrosion resistance and fatigue life in the studied steel.
\end{abstract}

Keywords. Strain hardening, roughness, hardness, residual stress, laser shock peening, water jet cavitation peening, water jet shot peening, ultrasonic impact treatment

Improvement in the surface properties of the end-products by changing their microrelief, grain structure, hardness, and residual macrostresses is very relevant due to the fact that the destruction of the materials depends usually on the surface structural state. It is well known that enhancing the operational properties of the metal components are largely provided by the surface plastic deformation (SPD) methods due to the formation of specific microrelief on the surface and fine-grained structure in sub-surface layers [1].

Currently, various peening methods, such as conventional shot peening (SP) [2], cavitation peening (CP) [3], laser shock peening (LSP) [4], ultrasonic impact treatment (UIT) [5], and hammer peening [6] are widely used for treatment both large-sized and small-sized metal components in the industry to provide severe plastic deformation of their subsurface layers. Herewith, a specific microrelief required is formed on the surface, the surface hardness is increased, and compressive residual macrostresses are provided as well. As a result, it allows increasing the wear resistance, corrosion resistance, and fatigue performance of the end products.

It should also be noted that the multi-pin UIT technique can be regarded as the most effective process to improve both the surface roughness and hardness of the surface layer [7]. The influences of the mono-pin UIT treatment on the material properties were recently reviewed as compared to the other peening techniques [8-10]. Therefore, the comparative studies of the multi-pin UIT technique with the WjSP, WjCP and LSP peening methods for mechanical surface treatment of stainless steel parts are virtually absent.

The aim of this work is to study and compare the effects of the LSP, WjCP, WjSP, and UIT on the surface roughness, hardness, and residual stresses of the austenitic stainless steel AISI 304.

The plane specimens $(48 \mathrm{~mm} \times 48 \mathrm{~mm} \times 3.0 \mathrm{~mm})$ of AISI 304 stainless steel were exposed to the laser shock peening (LSP), water jet cavitation peening (WjCP), water jet shot peening (WjSP), and ultrasonic impact treatment (UIT) processes (Fig. 1). The peening methods used were described in more detail elsewhere $[5,7]$. 
(a)

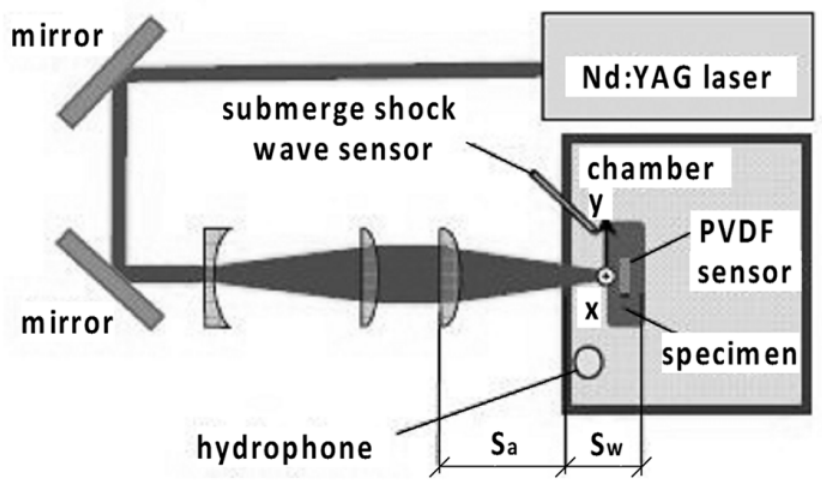

(b)

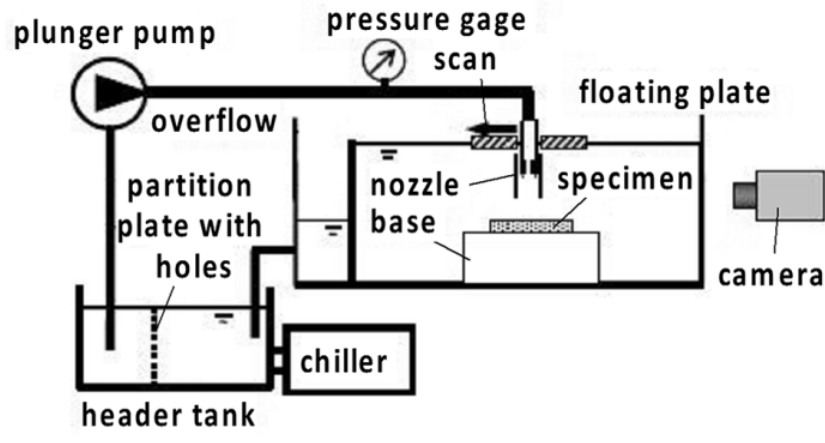

(c)

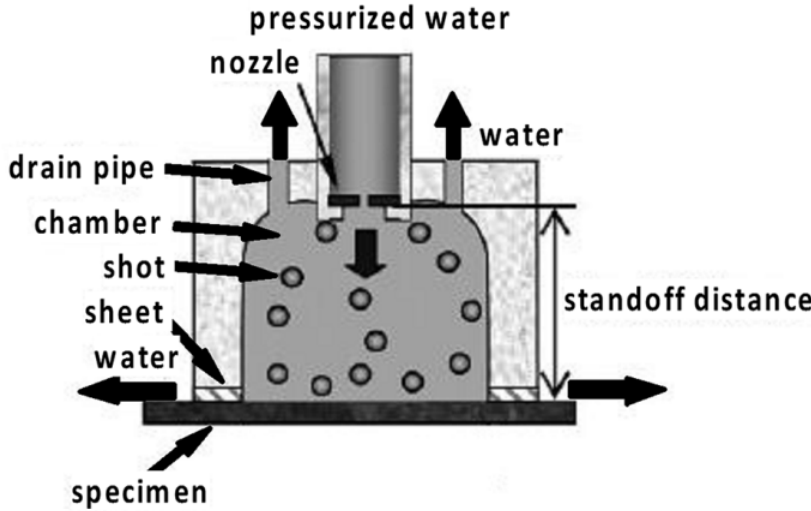

(d)

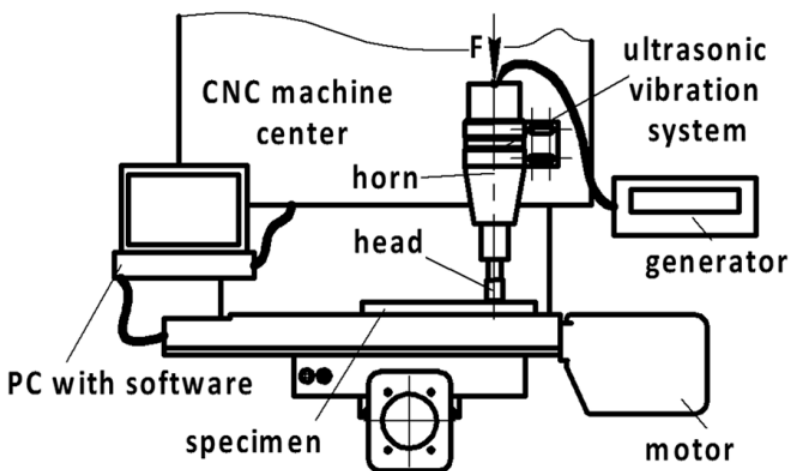

Fig. 1. Scheme of the $\operatorname{LSP}(a), \operatorname{WjCP}(b), \operatorname{WjSP}(c)$, and UIT processes $(d)$

The results showed that all peening methods used led to a reduction in the surface roughness of the treated surface (Fig. 2). In comparison with the untreated specimen ( $R a=3.06 \mu \mathrm{m})$, the average surface roughness of the peened specimens was respectively decreased by approx. $28 \%, 15 \%, 56 \%$, and $91 \%$ after the LSP, WCP, WSP, and UIT treatments. The most remarkable decrease in surface roughness $(R a=0.27 \mu \mathrm{m})$ was observed after the multi-pin UIT technique due to severe plastic deformation of high strain rate and high extent. As compared to the original state, the average surface roughness differs by more than an order of value in this case. The LSP and WjCP peened surfaces have roughness similar to that of the initial surface. It should also be noted that the surface roughness was slightly reduced after the WjSP technique via high $R a$ values of the surface roughness in the unpeened specimens (Fig. 2).

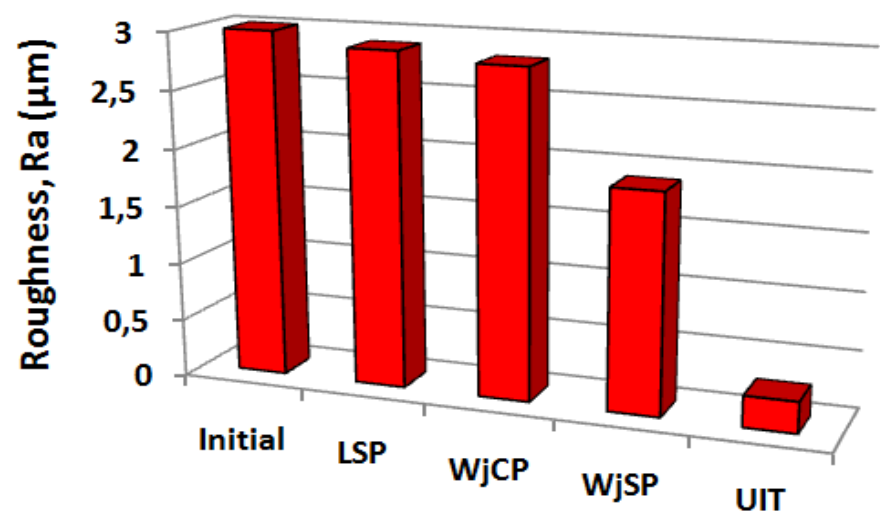

Fig. 2. Surface roughness of AISI 304 stainless steel after the LSP, WjCP, WjSP, and UIT treatments 
Regardless of the treatment type, the surface hardness increases relatively to the unpeened specimen due to the formation of ultrafine austenite/martensite grains (Fig. 3). The UIT and WjSP processes led to the highest surface hardness among the studied peening treatments. The LSP and WjCP of the used intensities demonstrate a saturation of the strain-induced hardening of the surface at the levels of $\sim 28 \mathrm{HRC}_{5}$ and $\sim 30 \mathrm{HRC}_{5}$, respectively. It should be noted that the hardening ability of the LSP process has not been exhausted for the studied regimes, and the hardness seems can be further increased [7].

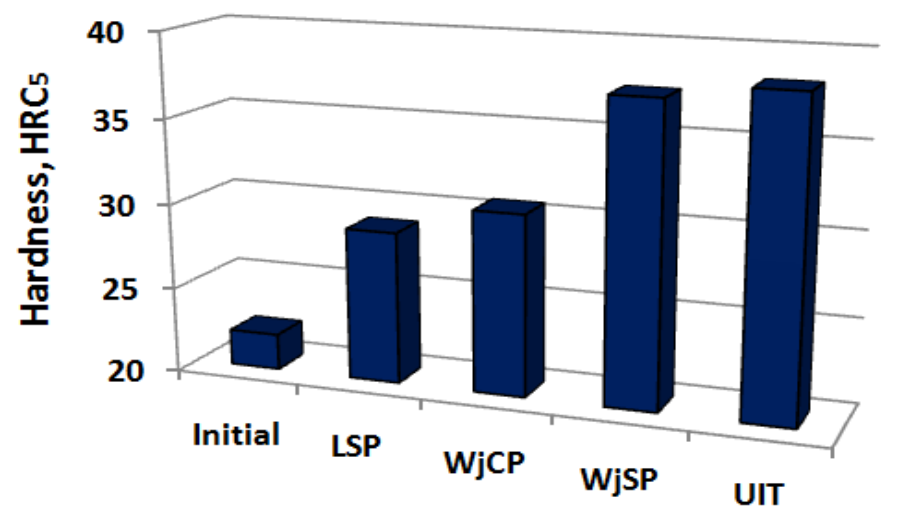

Fig. 3. Surface hardness of AISI 304 stainless steel after the LSP, WjCP, WjSP, and UIT treatments

The residual macrostress values obtained by the X-ray stress analysis are given in Fig. 4. The peening methods used led to a compressive residual stress formation. The $\mathrm{WjCP}$ technique induces the lowest residual stresses as compared to other cases. The WjSP and LSP methods induce the surface residual stresses of similar magnitudes regardless of the measurement direction $\left(\sigma_{\mathrm{X}} / \sigma_{\mathrm{Y}}\right)$. The highest magnitude of compressive residual stresses with regard to that of the unpeened surface was observed after the multi-pin UIT technique (-693 MPa).

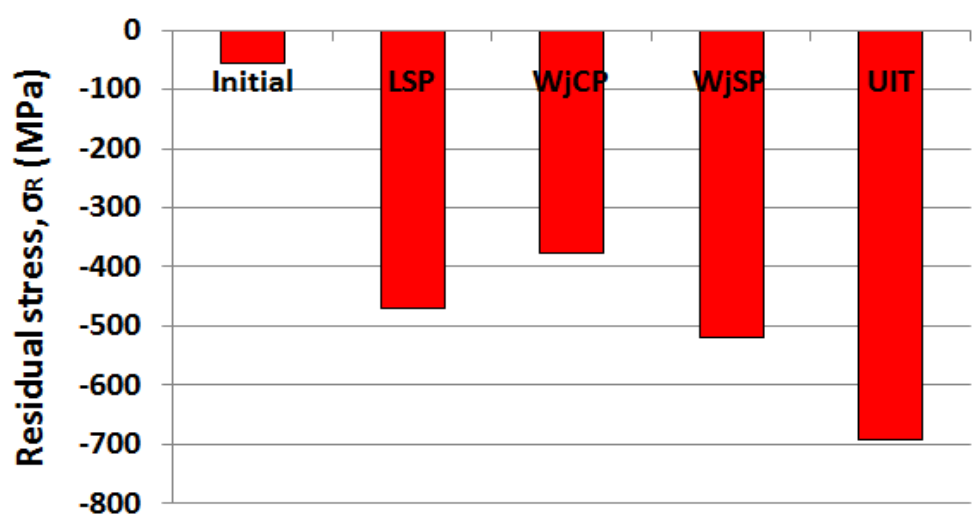

Fig. 4. Residual stress in the AISI 304 stainless steel after the WjCP, LSP, WjSP, and UIT treatments

Thus, the surface microrelief formed by peening techniques in combination with the hardened near-surface layers containing the fine-grained austenite/martensite microstructure and compressive residual stresses is expected to provide the enhancement in the wear and corrosion resistance, as well as the fatigue life of the studied steel. However, the enhancement extent depends on the treatment method used.

The effects of LSP, WjCP, WjSP, and multi-pin UIT treatments on the surface roughness, hardness, and residual stress of AISI 304 stainless steel were studied and compared. The obtained lead to the following conclusions: 
- As compared to the initial state $(R a=3.06 \mu \mathrm{m})$, the surface roughness was respectively decreased by approximately $5.5 \%, 7.8 \%, 38.2 \%$, and $91.1 \%$ after the LSP, WjCP, WjSP, and UIT treatments;

- The surface hardness $\left(22.1 \mathrm{HRC}_{5}\right.$ ) was increased after LSP (by 30.7\%), WjCP (by 38.4\%), WjSP (by 69.6\%), and UIT (by 73.2\%) treatments;

- All peening methods applied induced compressive residual stresses (ranged from $-377 \mathrm{MPa}$ to $-693 \mathrm{MPa}$ ) in the near-surface layer.

\section{References}

1. Azhari, A., Sulaiman, S, Rao, A.K.P. (2016), A review on the application of peening processes for surface treatment, Proc. IOP Conf. Series: Mater. Sci. Eng., Vol. 114, pp. 012002.

2. Iswanto, P.T., Maliwemu, E.U.K., Malau, V., Imaduddin, F., Sadida H.M. (2020), Surface roughness, hardness, and fatigue-corrosion characteristic of AISI 316L by shot peening, Metalurgija, Vol. 59, pp. 183-186.

3. Soyama, H. (2019), Comparison between the improvements made to the fatigue strength of stainless steel by cavitation peening, water jet peening, shot peening and laser peening, J. Mater. Process. Technol., Vol. 269, pp. 65-78.

4. Starman, B., Hallberg, H., Wallin, M., Ristinma, M., Halilovič, M. (2020), Differences in phase transformation in laser peened and shot peened 304 austenitic steel, Int. J. Mech. Sci., Vol. 176, 105535.

5. Lesyk, D.A., Mordyuk, B.N., Dzhemelinskyi, V.V., Prokopenko, G.I., Danyleiko, O.O. (2018), Influence of ultrasonic impact treatment on surface topography and microstructure of AISI 321 stainless steel, Sci. Review, Vol. 2/3(10), pp. 3-8.

6. Mannens, R., Uhlmann, L., Lambers, F., Feuerhack, A., Bergs, T. (2020), Surface integrity of AISI 52100 bearing steel after robot-based machine hammer peening, J. Manuf. Mater. Process., Vol. 4, 61.

7. Lesyk, D.A., Soyama, H., Mordyuk, B.N., Dzhemelinskyi, V.V., Martinez, S., Khripta, N.I., Lamikiz, A. (2019), Mechanical surface treatments of AISI 304 stainless steel: Effects on surface microrelief, residual stress, and microstructure, J. Mater. Eng. Perform., Vol. 28, pp. 5307-5322.

8. Gill, A., Telang, A., Mannava, S.R., Qian, D., Pyoun, Y.S., Soyama, H., Vasudevan, V.K. (2013), Comparison of mechanisms of advanced mechanical surface treatments in nickel-based superalloy, Mater. Sci. Eng. A., Vol. 576, pp. 346-355.

9. Gujba, A.K., Medraj, M. (2014), Laser peening process and its impact on materials properties in comparison with shot peening and ultrasonic impact peening, Materials, Vol. 7, pp. 7925-7974.

10. Turski, M., Clitheroe, S., Evans, A.D., Rodopoulos, C., Hughes, D.J., Withers, P.J. (2010), Engineering the residual stress state and microstructure of stainless steel with mechanical surface treatments, Appl. Phys. A, Vol. 99, pp. 549-556.

\section{Порівняння передових методів для механічної поверхневої обробки деталей із нержавіючої сталі}

\section{Лесик Д.А., Сояма Х., Мордюк Б.М., Мартінез С., Джемелінський В.В., Ламікіз А.}

Анотація. В даній роботі порівнюються різні методи механічної поверхневої обробки для поліпшення властивостей аустенітної нержавіючої сталі $08 X 18$ 10. Досліджено вплив лазерної ударної обробки (LSP), кавітаційної обробки у воді (WjCP), дробоструминної обробки у воді (WjSP) та ультразвукової ударної обробки (UIT) на шорсткість, твердість та залишкові напруження поверхні. Результати показують, що в порівнянні з необробленими зразками $(R a=3,06$ мкм), всі використані методи деформаційного зміинення демонструють зменшення параметрів шорсткості поверхні. Хвилястий регулярний мікрорельєф з найменшим параметром Rа утворюється після ультразвукової обробки. Твердість поверхні (22,1 НRC5) збільшилася на 30,7\%, 38,4\%, 69,6\% та 73,2\% відповідно після LSP, WjCP, WjSP та UIT обробки. Всі методи зміџнення викликають залишкові напруження стиснення (варіювалися від -377 МПа до -693 МПа) в приповерхневому шарі. Передбачається, що застосовані обробки можуть підвищити зносостійкість/корозійну стійкість $і$ втомну міџність в досліджуваній сталі.

Ключові слова. Деформаиійне зміцнення, шорсткість, твердість, залишкові напруження, лазерна ударна обробка, кавітаційна обробка у воді, дробостуминна обробка у воді, ультразвукова ударна обробка 